\title{
メタアクリール樹脂による骨補填術
}

\begin{tabular}{|c|c|c|c|c|}
\hline 熊本大学医学部第一外科学教室 & $\equiv$ & 浦 & & 義 \\
\hline & 宮 & 川 & & 全 \\
\hline & 瀬 & ノ. & 口 & 敬 \\
\hline & 内 & 田 & & 龍 \\
\hline
\end{tabular}

\section{Plastic Operation for the Bone-Defect with Methacreal Resin.}

By

\author{
G. Miura, Y. Miyagawa, K. Senoguchi \& T. Uchida \\ Department of Orthopedic Surgery Kumamoto University \\ (Direct. : Prof. T. Tamai)
}

骨の補填材として自家骨が最も勝れている事は論を またないが，頭蓋骨缺損部の補填或は下顎举切除後の 成形時には種々の制約があつて仲々利用しがたい。我 々は 1)メタアクリール樹脂が生体組織に対して殆 んど無刺㦸奥害であり 2) 入手がたやすく，3）造形 が極めて容易であり然も 4) 硬度及び機械的強度が 優秀である点に着目して, 自家骨では補填困難な大き な頭蓋骨缺損の補填材にメタアグリール樹脂を利用し て以来満 4 年 6 ケ月を経過した。其の間に 5 例の頭蓋 骨缺損の補填術並びに 1 例の造型術を施行して優秀な 成績を収め，又下顎骨の悪性腫煌根治術漈して自作 の人工下顎骨を使用して大体満足な結果を得たと考え られるので併せて此処にその一端を報告する。

症例は全例で 9 例であつて，種々のものがある。 症例 I は左側頭後頭部に発生した相当大きな外管腫 で我々の処に来る迄に 2 回の切除術を受けて居るが， 何れも短時日の中に再発して居る。我々は全骨腫を切 除し $8 \times 6 \mathrm{~cm}$ の大きな骨缺損部が出来ましたので此 処仙自作のメタアクリール樹脂肘で補搷した。術後満 4 年 6 ケ月の現在全く再発を認めず自覚症は殆んどな い。神経学的㛟査でも異常を認めないし脳波上にも特 別な所見を認めない。

症例 II は術前外骨睡と誤診したるのであるが，硬膜 下水腫によつて前頭部の頭蓋骨が圧迫され菲薄となつ て膨隆して居りましたもので学切除後補填術を行つ た。学校の成績の非常に優秀な学生であつたが術後も 成績は変らない。むしろ劣等感がとれてよく勉強出来

\section{ると云つて居る。}

症例 III は脳膜腫切除術後に出来た巨大な骨缺損のた めに，体位変換時の脳脱出感，眩量頭痛を訴兄頻繁に

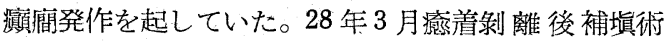
を行い上述の主訴はなくなり癭㾋様痤攣発作も全く消 失して, 現在術前の職業に従事して居る。

症例IVは前額部の巨大な肉腫切除に際して, 前頭洞 を損傷し，創に感染を来した。炎症が消失してから補 貸術を施行したが術後 5 日目より再度化澧して多量の 膿を排出していた。之はレヂン板を除去せず抗生剤の 注射のみで術後 3 週間目に完全に治痖退院し現在侗肉 腫及び化膿の再発も認めて居ない。

症例Vは陳旧陥没骨折で左半身の運動障碍，頭痛頭

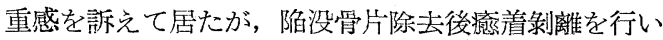
補填術を施行し, 現在頭痛及び頭重感は消失し, 運動 障碍も軽度となつて居る。

症例Иは下顎骨の癌で切除後自作した下顎骨で補経 した。術後一時化膿したが，そのま〉治癒した。

症例Иは細網肉腫で下顎骨を半分切除した。切除兴 にあわせて人工下顎骨を術中製作して装用した。口 腔内は腫禓部の粘膜を切除したので人工学の一部は粘 膜で被覆出来ず露出したままの部分が出来た。その為 術後感染を来して創より澧汁，垂夜を多量牒出して いたが，現在では創は殆んど治澺して居り，関節機能 も殆んど扮かされていない。 症例怔は術後経過日数が少ないので省略する。 以上簡単に症例を報告したが，斯粎な異物を生体内 
に応用するに際して私共の合頭を去らないのは感染の 危険でめる。私共の症例では頭蓋骨補填術に際して 5 例中 1 例, 下顎骨補填は 3 例中 2 例に感染をみたが之 等は症例で述べたように全て合成樹脂に原因があるの でなく, 術そのるの〉必然的な結果であると考兄る。 それにも拘らず，斯様な異物を除去する事なく創が治 癒すると云う事は現在迄の常識では考えられない点で あつて, この点のみを取り上げても私共はメタアクリ 一ル樹脂がむしろ自家骨に勝る合目的なものであると 確信して居る。

以下簡単に下顎の製作法を述べる。樹脂は市販の歯 科用のものを使用し, ポリマール(粉末) をモノマー ル (液) で溶して重合させる。切除骨でギプスの陰性 模型を作る。此の中に餅状になつた半重合体を圧入し
て約 40 分煮沸して重合させる。フラスクから取り出 せば完全な人工骨が出来る。此の間の所要㭙間は，丁 寧に作つて 70 分である。

以上メタアクリール樹脂による骨補填術について簡 単に報告したが, 詳細は後日熊本医学会誌上に発表 する。

\section{追 加}

鹿児島大学整形外科 宮 崎 淳 弘

9 例中 4 例飞化澧例があつたと云う事の原因をメタ アクリール樹脂の異物性に帰して居られる様である が, 骨は内藏と異り非常に感染し易いるのであるから， 手術操作又は樹脂の隇菌操作の上に原因があるのでは ないかと考光たい。

\section{大腿骨々折部に転移せる副腎腫の一例}

山口医科大学整形外科 大 石保

\section{A Case of Hypernephroma with Metastasis to the Fracture Site of the Femur}

By

T. Oishi

Orthopedic Clinic, Yamaguchi Medical School, Ube

患 者: 57 才，男 会社員

主 訴：右大眼部の疼痛。

現病歴：昭和 30 年 2 月 8 日朝, 自転車飞乗り 転 倒 し, 右大腿部に激痛を覚え, 同時に起立不能となつた。 既往症 : 昭和 28 年, 腎臟炎に羅患, $2 \sim 3$ 回血尿があ つた。

家挨歴：特記すべきものなし。

現 症 : 全身所見としては軽度の栄養低下を認める 他, 特記すべきものを認めず, 剭所所見としては, 右 大腿做漫性腫脹し, 右下肢を軽度外転, 外旋の肢位を とり, 大腿末梢三分の一の部分に圧痛及び維音を証明 す。

レ線写真所見：右大腿骨々体部骨折を認む。
入院後の経過及び処置 : 右大腿骨々体部骨折の診断 の下で受傷当日入院し，2月11日,キユンチャー髄内 釗固定術を行い, 術後腰部から足先に亘るギプス固定 乙経過観察す。術㷋経過良好, 仮骨形成子順調に進み 3 月 23 日右膝関節のマツサージ, 屈曲運動を開始し た。

5 月中旬より右季肋部に時々刺す様な疼痛を訴光始 めた。右季胁下に超手拳大の腄留を触れ, 圧痛はなく 尿量普通, 尿所見に異常は認めなからた。泌尿科診 察を受けたが，尿に異常なく結核菌も認める事が出来 なかつた。右季助部の疼痛はその後, 時々訴えるの久 で, 右季肋下の腫瘤もその大きさを堌さず, 大した変 化を認めながた。 